Dhaka Univ. J. Biol. Sci. 27(1): 75-83, 2018 (January)

\title{
EFFECTS OF FEEDING FREQUENCY ON GROWTH PERFORMANCES AND RNA : DNA RATIO OF THE GANGETIC MYSTUS (MYSTUS CAVASIUS HAMILTON, 1822) IN LABORATORY CONDITION
}

\author{
Mosheur Rahman, Mohammad Shamimul Alam¹ and Md. Golam Rabbane* \\ Department of Fisheries, University of Dhaka, Dhaka-1000, Bangladesh
}

Key words: Frequency, RNA:DNA, Growth, Mystus cavasius

\begin{abstract}
Experiments were conducted for a period of 90 days to estimate the effects of different feeding frequencies (one time per day: T1, two times per day: T2, three times per day:T3 and four times per day: T4) on growth performance of gulsha fish reared in laboratory facilities. Significantly higher condition factor was observed in T2 $(1.61 \pm 0.02)$ and lowest in T4 $(1.40 \pm 0.01)$. Significantly lowest SGR and ADG were recorded in T4 fish fed four times per day. No significant difference was obtained among different treatments for FCR and survival rate. The highest RNA : DNA ratio $(0.93 \pm 0.07)$ was observed in fish of T2 and the lowest ratio $(0.57 \pm 0.11)$ was observed in fish of $\mathrm{T} 1$. The results of the present study suggest that in laboratory rearing two meals per day could be supplied for better growth performances as per indication of condition factor and RNA:DNA ratio.
\end{abstract}

\section{Introduction}

The growth of fish at different stages of life mostly depends on the feed types, feeding regime, feed intake and its ability to digest and assimilation the nutrients. Role of feeding regime or frequency in commercial fish culture as well as early level survival and growth of fish has been reported as important factors to be considered (1-2). Use of a judicious feeding frequency is also important to minimize water pollution and production cost of commercially important fish(3).

Fish feeding time and frequency have been studied by many authors to investigate feed intake and growth performance of Labeo rohita, Heteropneustes fossilis, Oncorhyncus mykiss, etc. ${ }^{(4-6)}$. Therefore, it is important to identify optimum frequency and feeding rate of economically important fish species in aquaculture for their better production. When a fish is fed according to their requirement, FCR and growth will be improved due to regulation of its food consumption in relation to energy requirement ${ }^{(7)}$. So, feed management in terms of standardization of feeding rate and frequency has become one

\footnotetext{
*Author for correspondence: <rabbane@du.ac.bd>. ${ }^{1}$ Department of Zoology, University of Dhaka,
} Dhaka-1000, Bangladesh. 
of the vital areas of research in aquaculture. RNA:DNA ratio analysis is used to determine the growth condition of fish and it is based on the amount of RNA increase in the cell to systhesis protein where the amount of DNA is almost fixed in the cell. This approch has been successfully used in various aqatic organisms like fish, planktons and macroinvertebrates ${ }^{(8-9)}$.

The Gangetic mystus (Mystus cavasius) is one of the most popular and economically important fish in inland aquaculture because of its high market demand and good taste. It is widely distributed in Bangladesh, Pakistan, Nepal, India, Sri Lanka and Myanmar ${ }^{(10)}$. Nowadays it is commercially cultured in fresh water ponds of Bangladesh. To improve the culture of $M$. cavasius there is a need for understanding the culture management method in the area of feeding and feeding frequency to produce fish within a short time and at minimum cost and quality. Many researchers studied the effects of feeding frequency on growth of some edible and aquarium fishes ${ }^{(4,11-13)}$ but to the best of knowledge no information is available about the effect of feeding regime on growth and survival rate as well as RNA:DNA ratio regarding $M$. cavasius. So, the present study was undertaken to estimate the growth performances of $M$. cavasius under different feeding frequencies fed with micro-pelleted feed.

\section{Materials and Methods}

The Gangetic mystus (Mystus cavasius) was collected from the "Bhai Bhai Adarsho Matsho Hatchery" at Trishal, Mymensingh district. Fingerlings were transported with oxygenated polyethene bags and stocked in experimental tank at Aquatic Laboratory of Department of Fisheries, University of Dhaka.

The experiment was designed on four treatments (T1 : one meal/day, T2 : two meals/day, T3 : three meals/day and T4 : four meals/day) with three replications. Total 18 fish were randomly stocked in each tank with 30 liters water. The study was carried out for 90 days from August to October 2016. The fish were fed with commercial pellet diet named 'Optimum Micro Pellet' with 5\% of their body weight. The ingredients of supplied feed were fish meal, wheat flour, yellow corn, shrimp meal, spirulina fish oil, vitamins and minerals. The supplied feed contains crude protein $32 \%$, crude fat $4 \%$, moisture $10 \%$ and crude fibre $4 \%$.

Aeration was provided throughout the experiment. Water quality was monitored and the average values of dissolved oxygen, temperature, $\mathrm{pH}$ were found to be $7.7 \pm 0.86$ $\mathrm{mg} \Lambda, 24.2 \pm 2.45^{\circ} \mathrm{C}$ and $8.10 \pm 0.89$, respectively. After 90 days of rearing $30 \%$ fish were randomly collected by a fine mesh scoop net for growth measurement. During sampling, cold water was used for reducing the stress. After sampling, they were released carefully into the aquarium. To evaluate the growth of fishes and feed performances, average daily gain, specific growth rate, condition factor, feed conversion ratio and survival rate were assessed $^{(14-15)}$. 
For the determination of RNA : DNA, nucleic acids were extracted using CTAB extraction method with slight modifications ${ }^{(16)}$. RNAse was not used in the procedure. First of all, an amount of fish tissue $(0.48 \mathrm{~g})$ was grinded to a fine paste with approximately $2000 \mu \mathrm{l}$ of CTAB buffer. CTAB/fish extract mixture was transferred to a microcentrifuge tube. Proteinase K $(100 \mu \mathrm{gm})$ was added and the sample was inverted to mix up. The mixture was then incubated in water bath for 2 hours at $55^{\circ} \mathrm{C}$. The sample was centrifuged for 5 minutes at $14000 \mathrm{rpm}$ and the supernatant was transferred to another tube. An equal volume of $25: 24: 1$ phenol : chloroform : isoamyl alcohol was added and mixed well with the sample. The mixture was centrifuged at $14000 \mathrm{rpm}$ for 10 min. The supernatant was transferred to a clean microcentrifuge tube. To each tube, equal volume of isopropanol was added. The precipitate was isolated by spinning the tube at $14000 \mathrm{rpm}$ for $5 \mathrm{~min}$. The supernatant was removed and the DNA pellet was washed by adding two changes of ice cold $70 \%$ ethanol. All the supernatant was removed and DNA pellet was allowed to dry (approximately $15 \mathrm{~min}$ ). The DNA was not allowed to over dry or it would be hard to re-dissolve. The DNA was then dissolved in $10 \mu \mathrm{l}$ nuclease-free water and stored at $4^{\circ} \mathrm{C}$. Finally the quantity of DNA and RNA was measured by the Thermo Scientific Nanodrop 2000 Spectro-photometer with absorbance at $260 / 280 \mathrm{~nm}$. After calibration, $1 \mu \mathrm{l}$ of each sample was used for measurement of RNA and DNA. Average ratio of RNA and DNA was calculated for each frequency group and then compared.

All data were analyzed by using statistical package SPSS (Version 24; SPSS Inc., Chicago, IL, USA)with the level of significance at $\mathrm{p}<0.05$.

\section{Results and Discussion}

Highest average daily gain was obtained in T3 $(0.30 \pm 0.02 \mathrm{~g} /$ day $)$ fish fed 3 meals per day and lowest was recorded in T4 $(0.09 \pm 0.001 \mathrm{~g}$ /day) fish fed 4 meals per day (Fig. 1). Significant difference $(\mathrm{p}<0.05)$ in average daily gain was obtained among four treatments. The values of average daily gain of fish of T1 and T2 were $(0.16 \pm 0.014)$ and $(0.27 \pm 0.012)$, respectively.

Higher SGR was obtained in T1 $(2.66 \pm 0.11 \%)$ and T2 $(2.55 \pm 0.24 \%)$ when compared with T3 $(1.27 \pm 0.02 \%)$ and T4 $(0.76 \pm 0.02 \%)$ (Fig. 2). Lowest SGR was measured in T4 fish feed four times per day. However, no significant difference $(p>0.05)$ was recorded between T1 (fish fed one meals per day) and T2 ( fish fed two meals per day).

The fish of T2 was obtained highest condition factor $(\mathrm{k})$ value $(1.61 \pm 0.02)$ and fish of $\mathrm{T} 4$ was obtained lowest $\mathrm{k}$ value $(1.40 \pm 0.01)$. The $\mathrm{k}$ values of $\mathrm{T} 2$ and $\mathrm{T} 4$ differ significantly. But there was no significant condition factor differences between T1 and T3 fish fed feed 1 meal per day and 4 meals per day (Fig. 3).

Lowest FCR was measured in T2 $(1.78 \pm 0.10)$ and highest was measured in T4 (2.69 \pm $0.26)$. Highest survival rate was measured in T1 $(92.20 \pm 1.10 \%)$ fish fed one meal per day 
and lowest was recorded in T4 $(87.75 \pm 2.99 \%)$ fish 4 meals per day. No significant difference in FCR and survival rate was measured in Mystus cavasius fish in four different treatments (Figs 4 and 5).

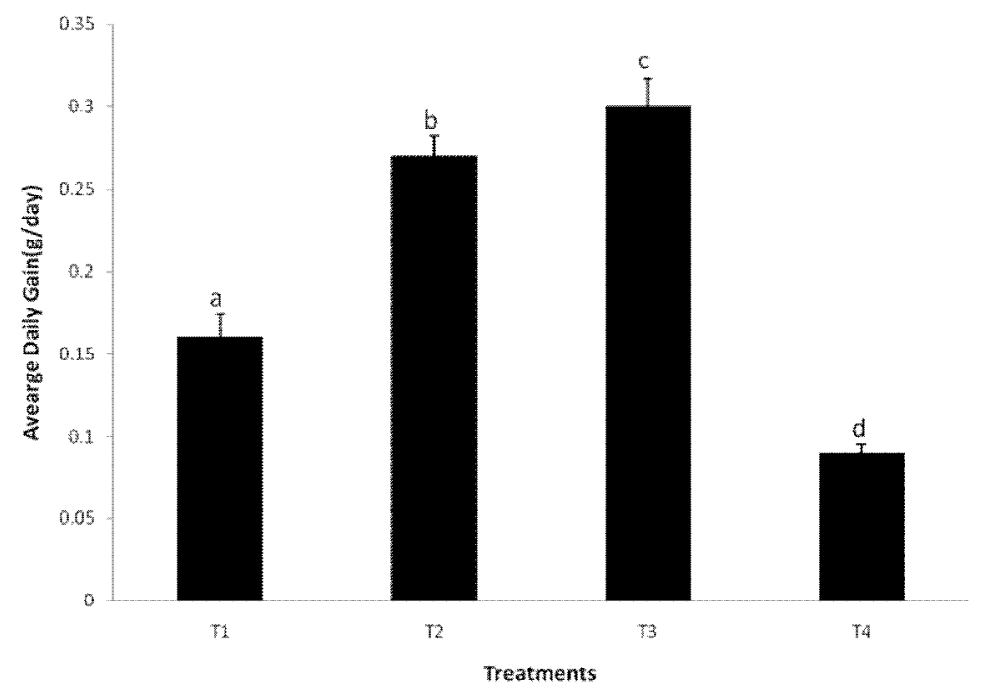

Fig. 1. Average daily gain (g/day) of Mystus cavasius in four different treatments cultured for 90 days. Bars with different letters are significantly different $(p<0.05)$.

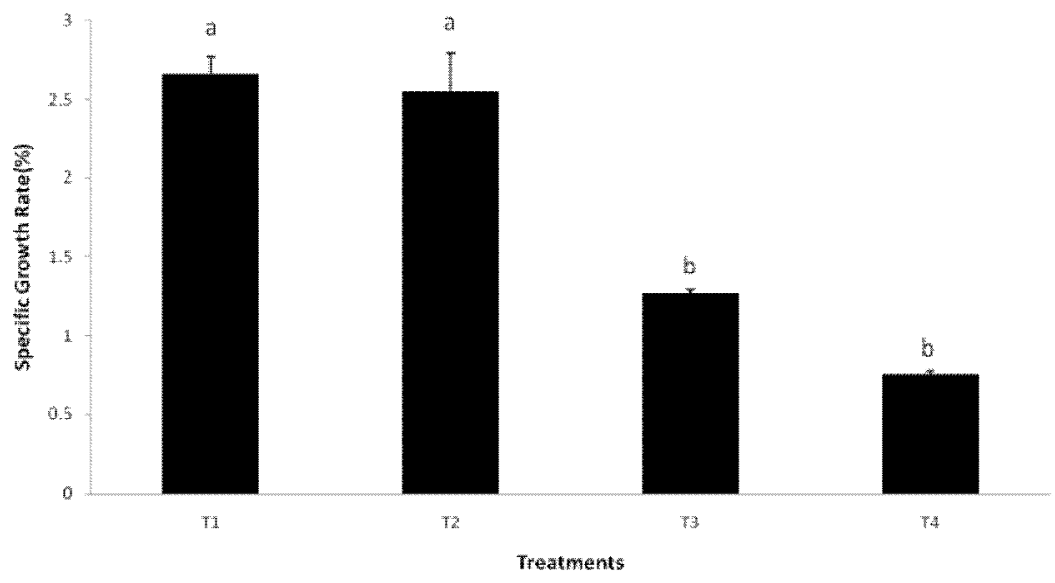

Fig. 2. Specific growth rate (SGR,\%) (Mean \pm SEM) of Mystus cavasius in four different treatments cultured for 90 days. Bars with different letters are significantly different $(\mathrm{p}<0.05)$. 


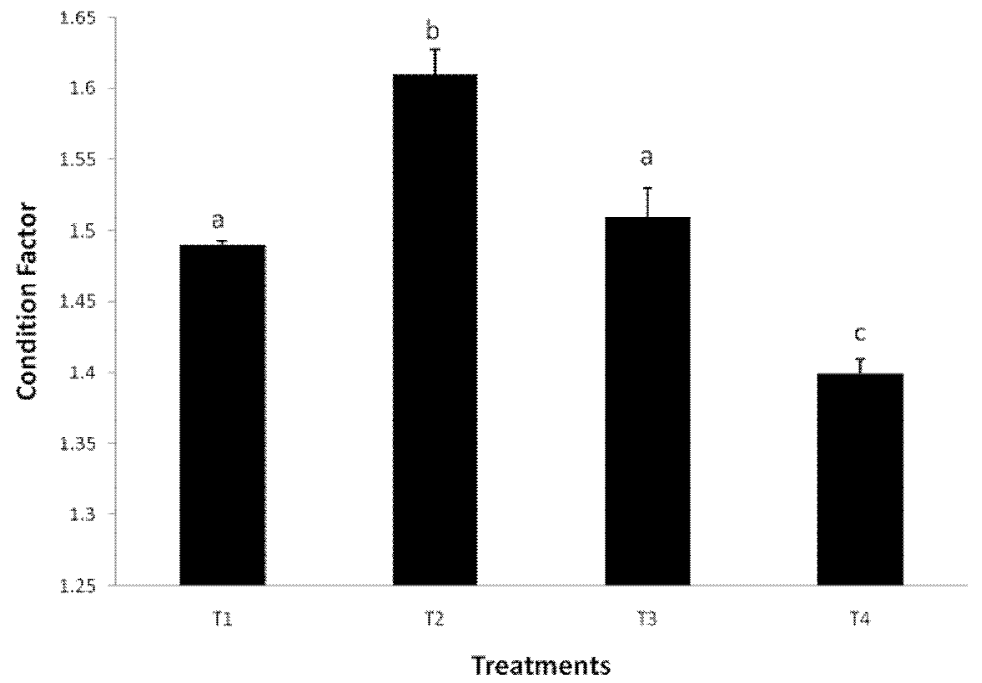

Fig. 3. Condition factor (Mean \pm SEM) of Mystus cavasius in four different treatments cultured for 90 days. Bars with different letter are significantly different.

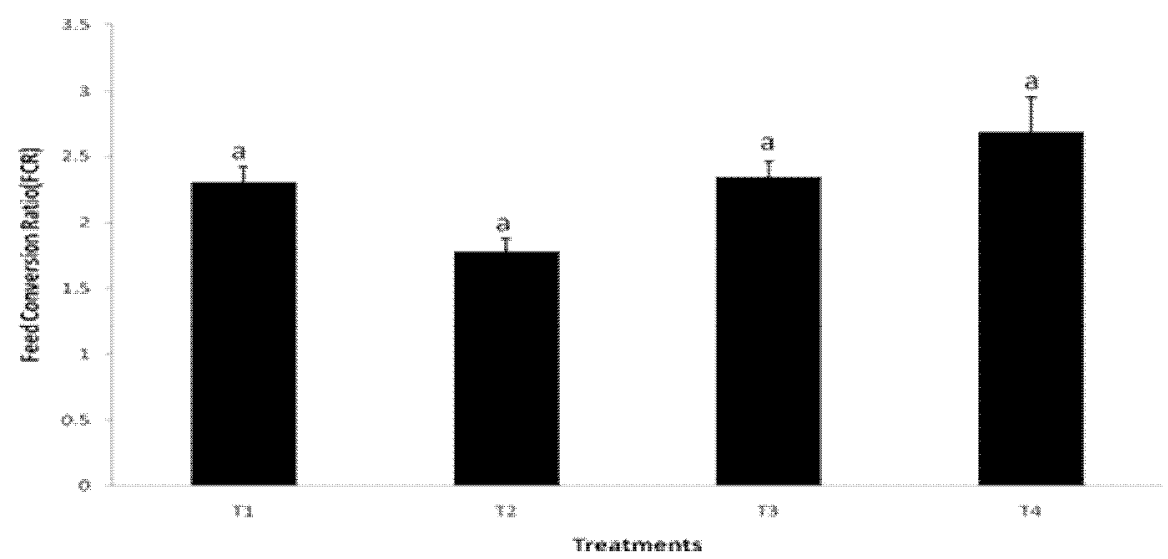

Fig. 4. FCR (Mean \pm SEM) of Mystus cavasius cultured for 90 days with four different treatments. .

Bars with same letter represent no significant difference $(p>0.05)$.

RNA and DNA levels in the tissue of Mystus cavasius in the different treatment groups are shown in Table 1 . The highest RNA : DNA ratio $(0.93 \pm 0.07)$ was observed in T2 whereas the lowest $(0.57 \pm 0.11)$ RNA : DNA ratio was observed in T1 (Table 1). The values were significantly different.

This study investigates the growth performance and RNADNA ratio of Gangetic mystus fish with different feeding frequencies during a culture period of 90 days. 


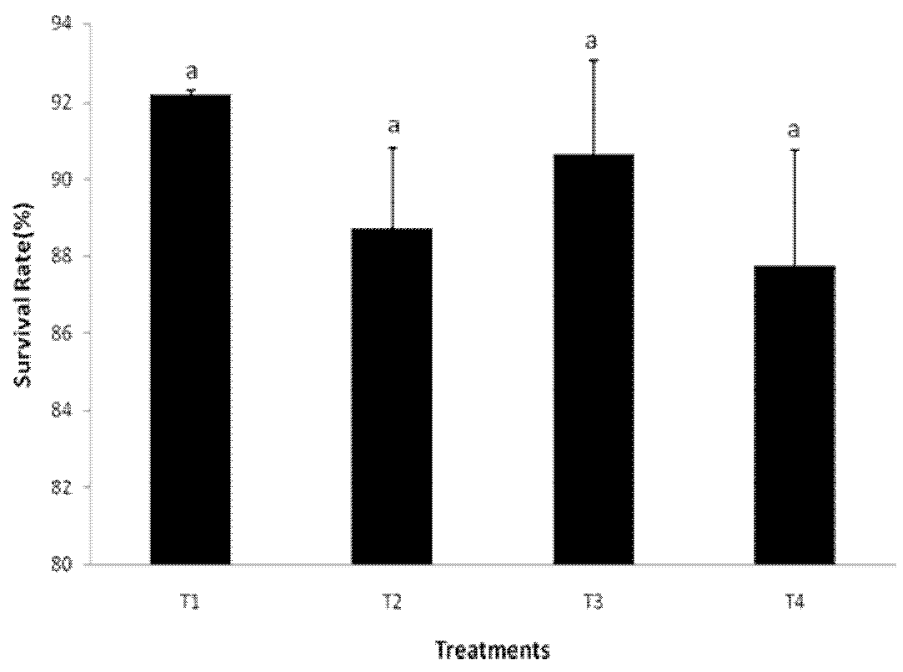

Fig. 5. Survival rate, $\%$ (Mean \pm SEM) of Mystus cavasius cultured for 90 days with four different treatments. Bars with same letter represent no significant difference $(p>0.05)$.

Table 1. RNA, DNA content, and RNA : DNA in the muscle of Mystus cavasius.

\begin{tabular}{llll}
\hline Treatments & RNA $(\mathrm{ng} / \mu \mathrm{l})$ & DNA $(\mathrm{ng} / \mu \mathrm{l})$ & RNA : DNA \\
\hline 1 & $30.70 \pm 2.67$ & $55.96 \pm 7.39$ & $0.57 \pm 0.11^{\mathrm{a}}$ \\
2 & $19.50 \pm 6.90$ & $34.70 \pm 14.20$ & $0.93 \pm 0.07^{\mathrm{b}}$ \\
3 & $50.26 \pm 13.35$ & $62.33 \pm 16.73$ & $0.81 \pm 0.004^{\mathrm{ab}}$ \\
4 & $20.73 \pm 3.38$ & $25.43 \pm 3.92$ & $0.81 \pm 0.008^{\mathrm{ab}}$ \\
\hline
\end{tabular}

Values are mean \pm SEM $(n=9)$. Means in the same column with different superscripts are significantly different at $\mathrm{p}<0.05$.

In average daily gain and specific growth rate, there are significant differences among different treatments. Lowest ADG and SGR are observed in T4 fish fed with 4 meals per day, whereas higher ADG and SGR are in T3 and T1, respectively. James and Sampath(18) observed highest growth and reproductive success in red swordtail (Xiphophorus helleri) that was fed twice a day in a cultured system, when compared with other feeding frequencies. But Guen-Up et al.(19) found that feeding to satiation once a day resulted in optimum growth of a commercial important black rockfish (Sebastes schlegeli).

Condition factor is one of the important growth parameters of this work and has significant difference among treatments. Highest condition factor value is observed in fishes fed with two meals per day and lowest with four meals per day. Thus, the results indicate that fish fed with two meals per day grows better than others. Actually, condition factor is an index to compare growth and fitness of fish based on the length and weight of fish. Rahman et al.(17) in a study on the survival and growth of catfish on 
selected supplemental feeds reported the values of condition factor between 0.81 and 0.87. But Kasiri et al.(11) did not find any significant difference in condition factor among four different feeding frequencies of angel fish though $\mathrm{k}$ values were more than 1 in case of all treatments indicating fairly better condition of the fishes. Thus, condition factor is also used as an index to compare growth and well-being of fish based on the principle that heavier fish of a given length is in better condition.

In the present study, there is no significant difference in FCR value and survival rate among different treatments. Present observation of FCR is in agreement with previous reports on cage-reared channel catfish ${ }^{(20)}$ and hybrid sunfish(21). Kasiri et al.(11) also studied the effects of feeding frequency on growth performance and survival rate of angel fish Pterophyllum scalare and found no significant different of survival rate among four different treatments (four meals per day, two meals per day, one meal per day and every other day).

Quantitative nucleic acid analysis offers an important tool for the measurement of fish growth rate. The increased level of RNA in a tissue is expected to show increased growth of somatic tissues, whereas DNA, genetic carrier of information, remains constant in somatic tissues and principally acts as indictor of cell number or biomass ${ }^{(22)}$. The concentration of RNA has been proposed as an indicator of nutritional status and growth of fish(23). Many authors, like Akhtar et al.(24) (Labeo rohita), Zehra and Khan ${ }^{(25)}$ (Catla catla), Smith and Buckley(26) (Gadus morhua) etc. have suggested that RNA:DNA ratio is an index of growth of fish. In the present study, highest RNA : DNA is measured in T2 fish fed twice daily and lowest $\mathrm{T} 1$ fish fed once daily.

It is evident from this study that feeding frequency has significant effects on the growth performances and RNADNA ratio of Gangetic mystus fish and feeding frequency up to 3 meals per day could be used for better growth to this fish in culture condition. However, further investigation should be carried out to observe the effects of feeding regime on growth of Gangetic mystus (Mystus cavasius) fish in culture pond condition.

\section{References}

1. Hung LT, NA Tuan and J Lazard 2001. Effect of supplementary feed on the growth of shing fish (Heteropneustes fossilis, Bloch). Bangladesh J. Aquac Trop. 16(2):171-184.

2. Dwyer KS, JA Brown, C Parrish and SP Lall 2002. Feeding frequency affects food consumption, feeding pattern, and growth of juvenile yellowtail flounder (Limanda ferruginea). Aquaculture 213: 279-292.

3. Oh S, BAV Maran 2015. Feeding frequency influences growth, feed consumption and body composition of juvenile rock bream (Oplegnathus fasciatus). Aquacult Int. 23: 175-184.

4. Choudhury BBP, DR Das, M Ibrahim and SC Chakraborty 2002. Relationship between feeding frequency and growth of one Indian Major carp Labeo rohita (Ham.) Fingerlings fed on different formulated diets. Pak. J. Biol. Sci. 5(10): 1120-1122. 
5. Sundararaj BI, P Nath and F Halberg 1982. Circadian meal timing in relation to the lighting Schedule optimizes catfish body weight gain. J. Nut. 112: 1085-1097.

6. Reddy PK, LF Leatherl, MN Khan and T Boujard 1994. Effect of the daily meal time on the growth of rainbow trout fed different ration levels. Aqua. Int. 2: 165-179.

7. Kaushik SJ and F Meadale 1994. Energy requirements, utilization and supply to salmoids. Aquaculture 124: 81-94.

8. Kyle M, J Schade, JJ Elser and T Watts 2003. A microfluorometric method for quantifying RNA and DNA in terrestrial insects. J. Insect Sci. 3: 1-7.

9. Foley CJ, DLBradley and TO Höök 2016. A review and assessment of the potential use of RNA:DNA ratios to assess the condition of entrained fish larvae. Ecological Indicators 60: 346-357.

10. Chakrabarty P and $\mathrm{HH} \mathrm{Ng} \mathrm{2005.} \mathrm{The} \mathrm{identity} \mathrm{of} \mathrm{catfishes} \mathrm{identified} \mathrm{as} \mathrm{Mystus} \mathrm{cavasius}$ (Hamilton, 1822) (Teleostei: Bagridae), with a description of a new species from Myanmar. Zootaxa 1093: 1-24.

11. Kasiri M, A Farah, and M Sudagar 2011. Effects of feeding frequency on growth performance and survival rate of angel fish, Pterophyllum scalare (Perciformes: Cichlidae). Veterinary Research Forum. 2: 97-102.

12. Hafeez-ur-Rehman M, KJ Iqbal, F Abbas, MMH Mushtaq, F Rasool, and S Parveen 2015. Influence of feeding frequency on growth performance and body indices of goldfish (Carrassius auratus). J. Aquac. Res. Development 6: 336.

13. Abid M, and MS Ahmed 2009. Efficacy of feeding frequency on growth and survival of Labeo rohita (Ham.) fingerlings under intensive rearing. The Journal of Animal \& Plant Sciences. 19(2): 111-113.

14. Karga J and SC Mandal 2016. Effect of different feeds on the growth, survival and reproductive performance of zebrafish, Danio rerio (Hamilton, 1822). Aquaculture Nutrition 23: 406-413.

15. Gonzales JM 2012. Preliminary evaluation on the effects of feeds on the growth and early reproductive performance of Zebrafish (Danio rerio). J. Amer. Assoc. Lab. Anim. Sci. 51(4): $412-417$.

16. Murray MG and W F Thompson 1980. Rapid isolation of high molecular weight plant DNA. Nucleic Acids Res. 8(19): 4321-4325.

17. Rahman MA, N Bhadra, N Begum and MG Hussain 1997. Effects of some selective supplemental feeds on the survival and growth of catfish (Clarias batrachus Lin.) fry. Bangladesh J. Fish. Res. 1(2): 55-58.

18. James R and K Sampath 2003. Effect of meal frequency on growth and reproduction in the ornamental red swordtail (Xiphophorus helleri). Israeli Journal of Aquaculture-Bamidgeh 55: 197-207.

19. Guen-Up K, S Jo-Young and L Sang-Min 2004. Effects of feeding frequency and dietary composition on growth and body composition of juvenile rockfish (Sebastes schlegeli). Faculty of Marine Biosience and Technology, Kangnung National University Gangneung. pp. 210-702.

20. Webster CD, JH Tidwell and D Yancey 1992. Effect of protein level and feeding frequency on growth and body composition of cage-reared channel catfish, Prog. Fish-Cult. 54: 92-96. 
21. Wang N, RS Hayward, DB Noltie 1998. Effect of feeding frequency of food consumption, growth, size variation, and feeding pattern of age-0 hybrid sunfish. Aquaculture 165: 261267.

22. Regnault M, and P Luquet 1974. Study by evolution of nucleic acid content of prepuberal growth in the shrimp Crangon vulgaris. Mar. Biol. 25: 291-298.

23. Bergeron JP 1997. Nucleic acids in icthyoplankton ecology: a review, with emphasis on recent advances for new perspectives. J. Fish Biol. 51: 284-302.

24. Akhtar MS, AK Pal, NP Sahu, A Ciji and SK Gupta 2012. Effects of dietary pyridoxine on growth and biochemical responses of Labeo rohita fingerlings exposed to endosulfan. Pestic. Biochem. Physiol. 103: 23-30.

25. Zehra S and MA Khan 2013. Dietary lysine requirement of fingerling Catla catla (Hamilton) based on growth, protein deposition, lysine retention efficiency, RNA/DNA ratio and carcass composition. Fish Physiol. Biochem. 39: 503-512.

26. Smith VJ, JH Brown and C Hauton 2003. Immunostimulation in crustaceans: does it really protect against infection? Fish Shell- fish Immunol. 15: 71-90.

(Manuscript received on 23 October, 2017; revised on 4 January, 2018) 